\title{
THE LEGACY OF A CULTURAL ELITE: THE BRITISH OLYMPIC ASSOCIATION
}

\author{
O legado de uma elite cultural: a Associação Olímpica Britânica
}

Dave Day
Jana Stoklasa

\begin{abstract}
Changes in the State's attitudes towards intervention in elite sport, particularly its willingness to invest through the National Lottery after 1996, resulted in Britain rising from thirty-sixth in the Olympic table in 1996 to second place in 2016. Government involvement marked a turning point for many long-established British sporting traditions, and this paper examines a significant influence on these traditions, the British Olympic Association (BOA), and its propagation of amateurism, an intangible cultural heritage $(\mathrm{ICH})$ generated by the cultural elites who formed and subsequently controlled the BOA. Cultural elites have the capacity to shape societal values through the application of their own principles, and their creation of an ICH is considered here through a case study that exposes the power relations that operate when considering heritage as a cultural transmission process. The authors highlight the functioning of an elitist circle, a 'cultural heritage elite', by exploring how a sporting aristocracy used their cultural power to impose their own hegemonic vision of how sport should be managed and played, resulting in a long-lasting ICH predicated on the principles of amateurism and the importance of the volunteer. This paper draws on a range of archives, including BOA records from the Olympic Study Centre in Lausanne, to illustrate the impact of this upper-class cultural elite on the development of Olympic sport in Britain and to demonstrate how they retained control for nearly a century before bureaucratic rationalization reduced their power and influence, although the authors also conclude that their legacy of class interests still resonates.
\end{abstract}

Keywords: Intangible Cultural Heritage; Amateurism; British Olympic Association.

\section{RESUMO}

Mudanças nas atitudes estatais em relação à intervenção no esporte de elite, particularmente na sua disposição de investir na Loteria Nacional depois de 1996, fizeram com que a Grã-Bretanha subisse do trigésimo sexto lugar no ranking olímpico em 1996 para o segundo lugar em 2016. O envolvimento do governo marcou um ponto de virada para muitas tradições esportivas britânicas estabelecidas há muito tempo e este artigo se examina a influência significativa sobre essas tradições, a Associação Olímpica Britânica (BOA), e sua propagação do amadorismo, uma herança cultural intangível (ICH) gerada pelas elites culturais que formaram e subsequentemente

1 Professor in Sports History. Manchester Metropolitan University - UK. E-mail: d.j.day@mmu.ac.uk. ORCID: http://orcid. org/0000-0002-6511-1014.

2 Associate Researcher in History. Philosophical Faculty, Institute for the Teaching of Democracy. Leibniz University, Hannover, Germany. E-mail: jana.stoklasa@idd.uni-hannover.de. ORCID: http://orcid.org/0000-0002-7994-5394. 
controlaram o BOA. As elites culturais possuem a capacidade de moldar os valores sociais por meio da aplicação de seus próprios princípios e a criação de uma ICH é considerada aqui por meio de um estudo de caso que expõe as relações de poder que operam quando se considera o patrimônio como um processo de transmissão cultural. Os autores destacam o funcionamento de um círculo elitista, uma "elite do patrimônio cultural", explorando nas análises como uma aristocracia esportiva usou seu poder cultural para impor sua própria visão hegemônica de como o esporte deve ser gerenciado e jogado, resultando em uma longa duração de ICH predicada sobre os princípios do amadorismo e a importância do voluntário. Este artigo baseia-se em vários arquivos, incluindo os registros BOA e do Centro de Estudos Olímpicos de Lausanne, buscando ilustrar o impacto dessa elite cultural de classe alta no desenvolvimento do esporte olímpico na Grã-Bretanha, bem como demonstrar como eles mantiveram o controle por quase um século antes que a racionalização burocrática reduzisse seu poder e influência, embora os autores também concluíssem que seu legado de interesses de classe ainda ressoa.

Palavras-chave:Patrimônio Cultural Imaterial; Amadorismo; Associação Olímpica Britânica.

\section{Introdução}

Sport is an example of culture, and as a contested sphere it is susceptible to the production of ideology and the core power relations of a society (HARGREAVES, 1986, 1987; GRUNEAU, 1983). This notion of sport as culture is intertwined with the development of broader perspectives surrounding the 'cultural turn' and acknowledging the inherently cultural nature of the sport makes it essential that researchers understand sport's relation to the wider culture (CHANEY, 1994). There are socially determined and culturally specific conditions in which sport is established and developed in particular societies, and at particular times, so it is especially important that sports are analysed in the context of societal culture and power relations. The 'invention of tradition' paradigm, for example, suggests that the continuities of national identity result from the artificial constructs of elite groups, imposed from above for the purpose of sustaining the established socio-political order (READMAN, 2005), and it seems that elites create collective memory guided by an ideology representing their interests (CZAJKOWSKI et al., 2016). Inevitably, therefore, although the way that sports are organized and played remains contested terrain, involving self-interested social groups and actors, they are always susceptible to the power of dominant groups (TOMLINSON et al., 2003). This process can be clearly illustrated by considering the nineteenth-century upper and middle-class interests who organized and structured their sport around their personal values and ambitions and left a sporting heritage that remained unchallenged for much of the twentieth century. The cultivation of that heritage was invariably undertaken by social elites operating in selected networks, such as the Olympic movement, through which they put into practice the presencing of the past as well as the forwarding of traditions' (DAY; STOKLASA, 2019).

The peculiar development of British sports participation at the Olympic Games can be directly attributable to the legacy left through the application of amateur values by an aristocratic elite that formed the British Olympic Association (BOA) at the start of the twentieth century. 
Keller suggests that 'strategic elites' are as old as the first organized human societies, and that, while there are variations in how these leading minorities have been selected, trained, and rewarded, recruitment through heredity is the most familiar. With the aristocracy, composed of families bound by kinship and wealth, a single stratum monopolizes the key social functions and represents a minority set above and apart from the rest of the population, with a special code of honour, etiquette, and outlook (KELLER, 2017). The argument in this paper is that, confident in their social and political status, a sporting aristocracy used their cultural power to marginalize other social groups and to impose their own hegemonic version of how the BOA should operate and the amateur values that it should espouse. The result was a long-lasting heritage in which the powerful aristocrat and the philosophy of amateurism remained a feature of the BOA throughout the twentieth century (DAY, 2012).

The paper discusses the formation and development of the BOA, details the way amateurism informed British Olympic discourses for over a century and highlights the significant changes that occurred in the British sporting landscape following substantial government intervention in the late twentieth century. This signified a critical shift in influence from a cultural elite to a centralized bureaucracy, epitomized by the quasi-autonomous non-governmental organizations ('quangos') established to distribute funding and resource elite performance, such as Sport England, UK Sport, and the English Institute of Sport. At the 2008 Olympics, Britain finished fourth in the medal table, winning nineteen gold medals, marking a significant turnaround from 1996 when Britain finished thirty-sixth. The London Olympics in 2012 saw Britain move to third in the medal table and the 2016 Games witnessed further advances by the British team as it rose to second, marking the first time that a host nation from one Games had managed to improve its standings at a subsequent Olympics. This upwards trajectory can be primarily attributed to a change in the British State's attitudes towards intervention in elite sport and to its willingness to invest heavily through the National Lottery. Since this funding stream began in 1997 more than 4,600 British athletes have benefited, resulting in the winning of 633 Olympic and Paralympic medals (UK SPORT: THE NATIONAL LOTTERY).

The authors draw on a range of archives, including BOA records from the Olympic Study Centre in Lausanne, to illustrate the influence of an upper-class cultural elite on the development of Olympic sports in Britain and argue that a dominant patrimony within British sport at the end of the nineteenth century, which had a vision of sport informed by their adherence to the amateur ethos, was able to set the agenda for British Olympic sport for over a century. It was only in the $1990 \mathrm{~s}$, through increased bureaucratic rationalization, that their control weakened and that perspectives on amateurism as an intangible cultural heritage began to change. The paper further argues that, despite the innovations of the last twenty-five years, driven by a tightly prescribed government agenda emphasizing targets for elite sports and athletes, the legacy of this intangible heritage is so powerful that the cultural elite responsible for the formation of the BOA still exerts an influence. 


\section{Class Influences}

It is important in the British context to understand the impact of social class and class attitudes to sport, which people use as a vehicle to distinguish themselves and to reflect status and prestige (BOOTH; LOY, 1999). As Bourdieu (1984) has pointed out, social classes constantly seek to accumulate capital in different forms. Economic capital is most easily thought of in terms of wealth, cultural capital in terms of artistic tastes, and social capital in terms of social connections, the tendency of individuals to associate together on a regular basis, to trust one another, and to engage in community affairs. At the core of the conventional definition of social capital is membership in 'purpose-built' organizations and voluntary associations, such as sporting clubs and National Governing Bodies (NGBs) of sport, which involved members in face-to-face interaction with others, engaged members in a common endeavour, and nurtured the capacity for collective action. On average, people in the middle class have twice as many organizational affiliations as those in the working class, and one study found that 52 percent of those at the top of the class structure had held office in an association as opposed to 19 percent of those in the bottom two class categories. There is also strong evidence that the upwardly mobile adopt the sociability patterns of the class into which they move (HALL, 1999).

All class factions work at accumulating forms of capital to enhance their social positions and use social practices like sport to maximize their capital and reflect and reinforce class distinctions. Upper-class status groups are characterized by inherited wealth, a reverence for tradition, allegiance to family, and a tendency to conservatism. They accept high status as a birthright, and they can socially distance themselves and preserve their dominant position by converting economic capital into social and cultural wealth. Maintaining dignity is paramount, and their preferred leisure pursuits stress manners, deportment, disinterestedness, refinement, self-control, and social distance. Their sports encompass strict rules of etiquette and ethical imperatives, which reflect their aesthetic tastes, and involve ideal-typical forms of 'body impression management'. In order to reinforce their status, the upper classes prefer leisure activities that can be performed at times and in places beyond the reach of other classes. They are free to play sport at midday, midweek, or 'out-of-season', and they have the resources to be able to play in exclusive and secluded places such as country clubs and private game reserves (BOOTH; LOY, 1999).

Relative to the upper classes, the middle class has limited economic, social, and cultural capital. Social capital is sparse, because social connections require economic capital and time, while cultural capital is scarce because it takes time, money, and social connections, to train, educate, and cultivate elite lifestyles. As a result, the middle classes generally focus on the future, on rising economically and socially, and tend to discipline their lives with precise amounts of time being allotted to work, play, family, religion. They adopt pragmatic, sensible, and utilitarian values, such as self-restraint, discipline, frugality, and piety combined with individual competitiveness. These patterns of socialization were common across the nineteenth-century professional middle classes who shared attitudes to speech patterns and modes of dress, while control of the body was manifested in the cult of health, characterized by sobriety, a moderate diet, anxiety about appearance, and adherence to the amateur doctrine of active participation (BOOTH; LOY, 1999).

Middle-class sports participants and administrators interact with their social superiors at school and at University. Education at Oxford and Cambridge universities (Oxbridge) has 
long been identified as a prime marker of 'establishment' status and, in his study of over 600 nineteenth-century students matriculating from Oxbridge, Rubenstein noted its role as the 'nursery of Cabinet ministers and the Whitehall-City elite' putting these universities at the heart of the 'British establishment'. In the twentieth century, 60 percent of all cabinet ministers have been products of Oxbridge, as have been most senior civil servants, judges, Anglican bishops, and a disproportionate percentage of Britain's intelligentsia (RUBENSTEIN, 2009). RUBENSTEIN (1993) also noted the influence of the public schools in gaining entrance to Oxbridge, not only from the 'elite' schools but also from those regarded as 'of a somewhat lower social cachet' (RUBENSTEIN, 2009). Honey and Curthoys (2000) found that 59 percent of men matriculating at Oxford between 1895-8 and 1911-14 were educated at a public school, with twelve to thirteen percent coming from a 'fringe' public school. Rubenstein (2009) concluded that, although Oxbridge did not provide a 'royal road' to the top, an Oxbridge education denoted a universally observed marker of likely candidates for elevation to the very highest positions.

After 1850 then, education at a major public school and Oxbridge in effect replaced aristocratic title and landed acreage, or close relationship with the old aristocracy, as the chief defining characteristic of the expanding middle and upper-middle classes (RUBENSTEIN, 2009). Not surprisingly, the emergence of an expanding and more inclusive middle class led to existing elites retreating behind their cultural boundaries. Elitism, and the elite culture it produced, drew a cultural drawbridge up to distinguish itself from and cut out the 'others' evident in Kant's 'principle of pure taste' which predicated aesthetic values and admired refinement, the attainment of virtuosity, and educated reflection. As Bourdieu (1984) argued, pure taste and its aesthetics were based on a rejection of the vulgar, simple, primitive, or popular and therefore constituted a social device or technique of distinction. 'Elite culture' is the cultural forms and institutions that were exclusive to, and a distinguishing characteristic of, social elites, was subsequently referenced to the cultural tastes of the established aristocracy, the commercial bourgeoisie, educated bureaucrats, political power brokers, and the professions. In the nineteenth century particularly, and long into the twentieth century, considerable energy was put into the creation of 'high' cultural institutional development (ELITE CULTURE) practices that were replicated in the sporting environment.

Despite their inferior position with respect to social and cultural capital, the educated middle classes reproduced upper-class attitudes with respect to the way that sports should be played, partly because they had often attended the same schools and universities as their social superiors. The creed adopted by both classes was amateurism, an ethical-moral value system that formed part of a 'civilizing' process of self-restraint and represented an extension of the 'athleticism' of the public schools and universities into the public arena. For the amateur sportsman, participation was as important as the outcome and the motivation to participate came from intrinsic rewards rather than extrinsic rewards of money and fame. The assumption was that a love of sport for its own sake would stimulate a climate of sportspersonship. 


\section{Amateurism as an Intangible Cultural Heritage (ICH)}

It is important that the ethos and spirit of amateur sport should not be confused with its basic principles. The commonly accepted ways of playing the game such as ideals of honorable, dignified and respectable behavior, not boasting in victory or complaining in defeat, not being too partisan, maintaining self-control and dignity, performing stylishly and with courage, and a focus on the manner of victory being more important than the margin, were all a matter of being a gentleman than of strict compliance with amateur principles. In many respects, amateur sport thoroughly mixed up aristocratic and bourgeois cultures. The spirit or ethos was essentially aristocratic while the principles and structures reflected middle-class attitudes, a combination that had a significant influence on the development of the Olympic movement, not least through its assimilation of these characteristics into an intangible cultural heritage (ICH), even though one official in a leading UK government heritage organization apparently believed that the 'UK has no intangible heritage' (SMITH, 2006).

Heritage can be seen as the material or intangible result of a fundamentally fictitious past, serving the ends of identity formation through the creation of a collective but selective memory. Harvey (2018) has argued that heritage should be understood more as a process, and a political and social construct than as 'present-minded' interpretations of physical artifacts. 'Heritage' indicates a mode of cultural production with reformative significance, a value-laden concept that is often represented by the notion of an inheritance bequeathed by previous generations to their successors. It encompasses immaterial cultural heritage, a set of practices, expressions, or representations that are acknowledged by human communities that constantly interact as being part of their heritage. When Smith asked visitors to heritage sites and museums to define heritage, foremost in many of the responses was the idea of heritage as memory, workplace skills, family histories, oral histories, or 'traditions' (SMITH, 2006). This ICH embraces a wide range of ideas, ranging from oral traditions to the social activities that 'people practice as part of their daily lives' (KURIN, 2004). While the contemporary world and emerging values always exert an influence, values and practices are generally transmitted from generation to generation, and constantly recreated by communities and groups in response to their environment and their history, providing them with a perceived sense of identity and continuity (LEIMGRUBER, 2010). The propagation of cultural heritage is often performed by actor groups that operate in selective and exclusive networks, be they 'power' elites (C. WRIGHT MILLS, 1956) and/or 'cultural' elites (BLAU, 1986, 1989). In the context of the discussion here it might be useful to think of 'cultural heritage elites' as defining those hegemonic functional groups who use intangible heritages to set symbolic boundaries and establish parameters for repertoires of inclusion and exclusion, 'insiders' and 'outsiders'. As a result of their powerful societal status, elite circles are able to utilize their capacity to influence others and their behavior in order to direct the production of cultural heritage, with its intangible values and manufactured traditions, in a way that satisfies their own purposes and philosophy (DAY; STOKLASA, 2019).

For SEWELL (1999), 'culture is a sphere of practical activity shot through by willful action, power relations, struggle, contradiction and change' and understanding the historically contingent and embedded nature of cultural heritage means engaging with debates about the production of identity, power and authority throughout society. Invoking cultural heritage is used by patrimonial elites to influence individuals and social groups, especially to instil loyalty, 
through the selective creation, preservation, (re)interpretation, and suppression (through concealment, discrediting, or destruction) of cultural narratives. Their direction and priorities are influenced by the setting of policies, by making laws, and in the allocation of resources (BUCKLAND, 2015). Patrimonialism, then, is a powerful form of elite privilege, one that allows its holders to achieve an autonomy that verges on autarky, the ability to appropriate resources from, and to exercise authority over, nonelites, and to legitimate this authority without needing the support of other elites (LACHMANN, 2011).

However, hegemony is not a static concept of dominance, which, once achieved, remains stable but it is an ongoing process, through which elites seek to co-opt, undermine, or override potential alternatives (WHITSON, 1984). Weber (1922) regarded patrimonialism as being both dynamic and durable, features epitomized by the way that power and influence were exerted by the small cultural elite who established a hegemonic grip on British sport at the end of the nineteenth century and whose philosophies and attitudes left such a long-lasting legacy. When this cultural elite graduated from the universities, their desire to extend their games into their post-university lives through the creation of associations led to a radical change in the sporting landscape. These men had no wish to mix with their social inferiors, so they structured their organizations and framed their sporting rules around their ethos of amateurism. Given the class obsessive society in which they operated, their powerful societal positions allowed them to impose this vision on all sports during the 1880s through the creation of NGBs and to dominate the leadership of the Olympic movement. The aristocratic circle that developed and sustained the BOA constantly employed and reiterated their sporting philosophy to the point that it became universally adopted as part of the nation's heritage.

\section{The Olympic Movement}

In June 1894, 79 delegates from thirteen countries and over fifty sports societies met to discuss amateurism and the revival of the Olympics Games, which they decided to hold at four-early intervals, starting at Athens in 1896. While proponents referred to ancient Greece for its ideal of physical prowess and the ennoblement of man in an athletic contest, they looked to Britain and its Public Schools for a modern interpretation of ancient ideals and for its structure. Delegates entrusted the organization and administration to an International Olympic Committee (IOC), which became the final arbiter in all matters concerning the Olympic movement. There was no pretense of democracy and the original fifteen members were not elected by, or representative of, their countries but invited by Coubertin who wanted members to be 'trustees' of the Olympic idea, and they were selected for their knowledge of the sport and their social status. Coubertin's IOC was a self-perpetuating body, composed of financially independent men, who valued internationalism above nationalism, and the IOC remains selfrecruiting with members co-opted. In many respects, Coubertin's IOC outwardly conformed to Weber's ideal type of a formal, rationally organized bureaucracy with clearly defined goals and patterns of activity accompanied by acceptable regulations and controls functionally related to the attainment of goals. However, Michel's 'iron law of oligarchy' is probably more appropriate given that oligarchy, rule by the few, arises even in the most idealistic of organizations, the ideals over time serving as mere rationalizations to preserve power in the hands of a select 
group (TOLBERT, 2010).

Two of the IOC members appointed by Coubertin were British. Charles Herbert, Honorary Secretary of the Amateur Athletic Association (AAA) from 1883 to 1906, had helped to organize the 1894 Congress, and he was highly thought of by Coubertin, who described him as part of the 'immovable trinity' at the head of the IOC. He was born in India, where his father was a serving Army officer, but he returned to England for schooling. On leaving school he was a successful oarsman, winning the Silver Goblets at Henley in 1876 and, as a runner, he was the half-mile and one-mile champion of the Civil Service, in which he served as a finance official. Lord Ampthill, the son of the British Ambassador to Germany, was selected by Coubertin presumably because he felt he needed someone with more impressive social credentials than Herbert to represent Britain. Ampthill was born in Italy where his father was on special assignment, but he returned to England for schooling and succeeded to the title on death of his father in 1884. He was an outstanding oarsman at Eton, where he first met Coubertin in 1888, and he rowed for Oxford University alongside another future IOC member, Theodore Cook. He also enjoyed success at the Henley Regatta, winning the Silver Goblets with Guy Nickalls in 1890 and 1891, and he was a member of the Leander eight which won the Grand Challenge Cup in 1891. Ampthill was appointed Governor-General of Madras in 1900, and he served briefly as Governor-General of India. Like many influential persons in British sport, he was a prominent freemason and was Grand Master of the Grand Lodge of England in 1908.

\section{British Olympic Association (BOA)}

The IOC held its fourth session in London between 20-22 June 1904, the main organizers of this meeting being the then British representatives on the IOC, Sir Howard Vincent, the Rev Robert Stuart de Courcy Laffan, and Charles Herbert. The visit led to the formation of the British Olympic Association (BOA) in the House of Commons on 24 May 1905 when William Henry Grenfell MP, later Lord Desborough, was elected as its first chairman with de Courcy Laffan as its honorary secretary. The BOA was structured along the same lines as the IOC and it adhered to the same principles. Its remits were to spread knowledge of the Olympic movement in Britain, to guarantee that the views of British sporting associations were represented in the organization of the Olympic Games, to ensure the participation both in the Olympic Games and international athletic congresses of representatives properly accredited by official sporting associations, and to facilitate their attendance. The original committee was made up of members from seven national governing bodies of sport, the majority from the privileged classes (BARKER, 2005). Class differences between the upper and educated middle classes became apparent from the start as the upper class took over the Association as leaders, utilizing their cultural and social capital to further the aims of the BOA, while the middle classes acted as administrators.

This first committee was dominated by representatives of the privileged classes, particularly those key personnel who were also IOC members. Nine of the sixteen members, whose schooling had included Eton, Harrow, Rugby, Westminster, and Radley, had been to Oxbridge (seven Oxford, two Cambridge), five were Members of Parliament (MPs), and career 
paths were dominated by the Law, the Military, Education, and the Civil Service. Member of Parliament (MP) William Henry Grenfell, Lord Desborough of Taplow, was an IOC Member from 1906 to 1909 and BOA Chairman from 1905 to 1913. He was educated at Harrow and Oxford and an outstanding all-round sportsman who became chief organizer of the 1908 Olympics and President of five national governing bodies. The Rev. Robert Stuart de Courcy Laffan, an IOC member between 1899 and 1927, was Honorary Secretary of the BOA from 1905 to 1920 and acting Chairman between 1920 and 1922. He went to Winchester public school and Oxford, before becoming a Church of England vicar and a public-school headmaster. Sir Theodore Andrea Cook, an IOC member from 1909 to 1915, was an oarsman and fencer who was best known as editor of the sporting periodical, The Field. Colonel Sir Howard Vincent went to Westminster School and Royal Military College, Sandhurst, before pursuing a career as a soldier before developing Scotland Yard as its Director of Criminal Investigations and then becoming an MP. Several other BOA members were MPs. Sir Lees Knowles was a politician and barrister who was educated at Rugby School and Cambridge, where he was President of the Athletics Club. William Hayes Fisher, later Lord Downham, President of the National Skating Association, was a barrister and MP who was elected Chairman of the BOA in September 1919. Reginald Gridley, barrister, and MP, who was rowing's representative on the BOA, went to Eton and rowed for Cambridge. Other members had garnered significant social capital through their connections to Oxford University. Lord Montagu of Beaulieu had rowed at Oxford, while Colonel Sir Henry Walrond, Honorary Secretary of the Royal Toxophilite Society, and Captain Alfred Hutton, president of the Amateur Fencing Association, had attended Oxford before pursuing their military careers (BARKER, 2005).

A few suitably respectable and well-connected middle-class representatives of important sporting associations supported these core individuals. Thomas Walter John Britten, treasurer of the National Cycling Union had attended the 1894 meeting which founded the IOC and worked as a civil servant in the Board of Trade as an Official Receiver in Bankruptcy. Sir George Rowland Hill, Honorary Secretary of the RFU from 1881-1904 before becoming the eighteenth President of the RFU and also a member of the International Rugby Board from 1890, was a record keeper in the Principal Probate office at Somerset House and a member of London County Council. He was knighted in 1926 for services to the game. Edward Lawrence Levy, who won the first British Weightlifting Championship in 1891 and was Honorary Secretary of the Amateur Gymnastic Federation ran a Jewish School in Edgbaston in the 1870s and 1880s before pursuing a career in journalism. Edgar Morris Wood Syers, who had been an art student in 1881, was the only representative of a winter sport. He founded the Great Britain Ski Club in 1903 and represented the organization on the first Olympic council, although it was in ice skating that he actually competed at the Olympics. Sir Frederick Joseph Wall, whose father had been a Carpenter, started with the London Football Association in 1881 and became an FA Council member on behalf of Middlesex in 1891-1895. Later he became Secretary of the Football Association in 1895, a post he held until his retirement in 1934, and he was knighted for services to Football. At the 1908 Olympic Games, he was in charge of press operations, and he subsequently wrote an account of his life, Fifty Years in Football (BARKER, 2005).

At the time of the London Games in 1908, little seems to have changed. Lord Desborough was Chairman, and de Courcy Laffan was still Honorary Secretary while several other founding members were still on the Committee, which had now been extended, partly to facilitate the organization of the Games. While this expansion had created the potential for 
a degree of democratization in the BOA, this never actually materialized because the cultural elite retained control of key committee positions, with the first six presidents and ten of its first thirteen chairpersons holding aristocratic titles (DUNCAN, 1976). This elitism was reflected by the large proportion of university men, including twelve Oxbridge 'blues' (men who had represented their University at a sport), in the track and field team at the 1912 Olympics leading one critic to observe, 'Caste rules the world of athletes and all is snobbery... At present, the whole tendency seems to be that only public school and university men shall have all the chances. Those who control the British contribution to the Olympic Games would like to see Britain represented by nice young men with nice pedigrees and splendid educations' (THE LITERARY DIGEST, AUGUST 31, 1912).

At Stockholm, the only British victories were in the 1,500 meters and the 400 meters relay, leading to an outcry at home as further proof of national decadence, and the Saturday Review (AUGUST 17, 1912) complained that although Britain had taught the world to play games for fun, other nations now made it a business. The failures in Stockholm did, however, stimulate a debate that challenged some of the key pillars of British sporting heritage with one Times (OCTOBER 22, 1913) correspondent arguing that everyone outside the "charmed circle of the public school' should have opportunities, a recognition that it was within the public schools and the associated social class that the intangible cultural heritages of British sport were most entrenched.

\section{Inter-War Period}

The interwar period saw English culture animated by attempts 'to ally preservation and progress, tradition and modernity, city and country in order to define Englishness as orderly and modern' (MATLESS, 1998). Perkin (1989) described inter-war society as being in a 'transitional stage, a sort of halfway house in which remnants of Victorianism...co-existed with harbingers of the future' and this appears to have been true of all aspects of social, cultural, political and economic life, including sport, where class dynamics continued to exert a powerful influence. Consequently, amateur values continued to take precedence, emphasizing the power invested in British sport's patrimonial elite. Amateur administrators, who believed that Britain had little to learn from foreigners and that the British sportsman was inherently superior, continued to laud their way of playing sport, of seeing sportsmanship as a distinctively British characteristic, a moral value that could be extended to all spheres of conduct (HUGGINS; WILLIAMS, 2006).

Within the BOA, aristocratic leadership continued. When the Association met in Russell Square in September 1919 and agreed to compete at the Olympics in Antwerp, William Hayes Fisher, now Lord Downham, was installed as Chairman and when the BOA investigated the state of track and field athletics in 1923 its Commission, headed by aristocrat Lord Decies, was sprinkled with University and military men, reflecting the composition of the BOA itself. In 1926, a later BOA chairman and IOC member Lord Rochdale took advantage of the new medium of radio to give a talk on the Olympics, and by the time of the Berlin Olympics Lord Burghley, already an IOC member had become BOA chairman. As the aristocracy had always done in all aspects of their lives, BOA leaders used-acceptable middle-class individuals as servants to administer their Olympic project. Examples abound. John Wadmore was manager 
of the 1928 Olympic Team in Amsterdam, where Denis Lyons acted as a referee, and Arthur Turk, the 'Grand Old Man' of British athletics and a life vice-president of the AAA oversaw the 1932 and 1936 Olympic teams (STAR GREEN 'UN, AUGUST 10, 1957).

For both the aristocracy and the bourgeoisie, amateurism continued to be the underlying philosophical imperative. Writing on rugby, W.W. Wakefield (1927) exposed many of the key concerns of the amateur elite about contemporary sport. As a past captain of Cambridge University and a rugby international, he emphasized that 'Rugger' was first and foremost a team game, and, though it should be played to win, the game must never be subordinated to the result, especially in International matches, 'lest they should become gladiatorial contests rather than friendly trials of strength between two countries'. Ten years later, the AAA reiterated that they were concerned with 'exercise for the multitude, rather than competition for the specialist,' (AAA MEMORANDUM, MAY 10, 1937) reflecting their ongoing efforts to develop volunteers from their own social class, such as the several amateur coaches appointed to the Loughborough summer school for athletics in 1935 (YORKSHIRE POST, FEBRUARY 5, 1935). Some of these men appeared again later that year in a longer list of athletes and officials willing to give talks, lectures, and demonstrations to clubs and schools. As keen amateurs, 'no fee was to be charged for their services', and the composition of this list reflected the traditional profiles for amateurs with representatives from educational institutions (49\%), the armed forces $(6 \%)$, medicine $(6 \%)$, law and finance $(14 \%)$, as well as other middle-class occupations (17\%) (MANCHESTER GUARDIAN, DECEMBER 13, 1935). Although Britain won only two track gold medals in 1936, apologists for the British team argued that 'our own particular amalgam of work and play expressed a better philosophy of life than those other codes which have reaped superior honours at Berlin.' Most importantly, British athletes had competed as a 'gentleman' should (DAILY EXPRESS, AUGUST 14, 1936; DAILY MIRROR, AUGUST 14, 1936; OBSERVER, AUGUST 16, 1936).

\section{Post-World War II}

In the immediate post-1945 period, NGB administrators continued to promote amateur values. In many ways, the cultural heritage of amateurism acted as a form of nostalgia for an earlier age, highlighting how an intangible heritage, through memory and received wisdom, can act as a powerful agent in perpetuating traditions and social practices. Despite significant changes in English society, amateurism continued to exercise a powerful grip over the practice and administration of British sport into the second half of the twentieth century (BAKER, 2004), even though there were continuing anxieties over the international competitiveness of British athletes across all sports. At the Helsinki Olympics, for example, Britain's first gold medal came on the last day, and then it was won by a horse (BRAILSFORD, 1992), leading to extensive criticism over the 'ghastly failure' of the British team (THE TIMES, AUGUST 7, 1952). A Picture Post correspondent declared that the only solution was to get rid of this 'absurd smugness about amateurism' (PICTURE POST, FEBRUARY 2, 1952), while another observer observed that, 'What's the use of 'being British' and saying 'the game's the thing - not the result'? No other country enters in that spirit. No other country comes off so badly. Either we should go flat out to win - or not enter' (PICTURE POST, AUGUST 9, 1952). 
While a growing interest in the pursuit of excellence began to emerge in the 1950s and early 1960s (ANTHONY, 1980), any developments remained contingent on persuading those whose sporting lives had been dictated by their allegiance to Britain's ICH that they should compromise their attitudes towards amateurism and voluntarism. This was always going to be difficult. In 1953, the AAA secretary, E.H.L. Clynes, observed that:

\begin{abstract}
The association is, however, not only concerned with champions but with the average young man who wishes merely to participate in a healthy outdoors recreation, to build up a fit body and mind, in the friendly company of other athletes. Too much emphasis cannot be given to the fact that amateur athletics is primarily and always a recreation (AAA ANNUAL REPORT, 1953).
\end{abstract}

Roger Bannister argued in 1955 that Britons should 'continue to be ourselves'. He suggested that 'To regard sport as a hobby is surely more of a virtue than a vice and is much closer to the Greek ideal of the complete man than is the athletic machine'. If Britain kept 'our own attitude other countries will respect us more, and we shall still enjoy our sport' (BANNISTER, 1955). Harold Abrahams also later condemned the amount of prestige attached to winning an Olympic gold medal and 'the fuss that sections of the public make, encouraged by the press, when an athlete loses a gold medal by half an inch' (ABRAHAMS, 1968). Indeed, there were further calls to abandon the Games altogether because the values of friendly internationalism had now been replaced by the 'grueling (sic) fanatical training of some of the competitors' which ruled out 'most people's ideas of amateur sportsmanship' (PICTURE POST, DECEMBER 31, 1956).

The trend to turn to the aristocracy for Olympic leadership continued into the second half of the twentieth century, and, despite significant changes in English society, the cultural elite continued to control Britain's Olympic movement. On 7 May 1951, Lord Luke of Pavenham was appointed as an IOC member. After schooling at Eton, he had attended Cambridge University where he was a notable athlete and oarsman. He was director of several commercial companies, a trustee of various leading charities and, like two of his predecessors on the IOC, General R. J. Kentish, and Sir Noel Curtis-Bennett, he was Chairman of the National Playing Fields Association. At 83 he retired from the IOC to make way for Princess Anne, who competed at the 1976 Montreal Games, when another aristocrat, Lord Rupert Nevill, led the delegation as Team Commandant. This BOA cultural elite consistently resisted both commercialization and professionalism. Speaking in 2012, Hamilton Smith, National Technical Officer for the Amateur Swimming Association (ASA) from 1963-1967, reflected on the 'aristocratic' and altruistic attitudes of amateur officials, noting that, in his view, there was an upper-class element still controlling amateur sport. If their authority was questioned that was when 'problems arose' (CARPENTER, 2012). Ultimately, the only effective challenge to the legacy left by this highstatus group came from an even more powerful influence, the government. 


\section{Government Involvement}

While British participation in the Games was initially informed by the values and ethos of a late-nineteenth-century patrimonial elite, there is evidence that government intervention at the end of the twentieth century resulted in a significantly different approach. Since participants typically represent social organizations or communities, their victories are often taken to be an indication of group superiority, and the outcomes of sporting contests, particularly at international level, are frequently interpreted politically (HOULIHAN, 1998). In a twentiethcentury world consumed by concerns over national identity, sport became a way of asserting national status, so it is not surprising that many countries industrialized their approaches to international competition. Even though British administrators resisted adopting practices that they considered as being inconsistent with their sporting heritage, the British State was not entirely ignorant of these developments. In 1959, the Foreign Office acknowledged that the Olympics had 'immense prestige, and offer a unique stage for the demonstration of national prowess' (FOREIGN OFFICE, JULY 16, 1959), while the influential 1960 WOLFENDEN REPORT recognized that international sporting contacts had a potential to 'yield rich dividends in international understanding'. Eventually, the British government was persuaded to intervene more directly in elite sport through a process of bureaucratic rationalization, moving the direction of Olympic sports away from the direct control of the upper-class elite.

'Rationalization' refers to the replacement of traditions, values, and emotions as motivators for behaviour in society with concepts based on rationality and reason. Max Weber argued that bureaucracy constitutes the most efficient and rational way to organize human activity and that systematic processes and organized hierarchies are necessary to maintain order, maximize efficiency, and eliminate favouritism. In Economy and Society, he described a bureaucracy as a 'structure of domination' and argued, more precisely, that 'bureaucratic administration means fundamentally domination through knowledge'. The bureaucratic form is different from its underpinning bureaucratic rationality, a domination through knowledge, or the means of its acquisition. It is the mundane, seemingly insignificant acts of semantics, drawing definitional boundaries, rules, procedures, codes, protocols, and writing the world in formalized terms, that enables it to be known, become predictable, and be acted upon. As such, bureaucratic rationality allows bureaucratic structures to function, and it persists, sometimes even expanding, even when the organizational form identified as bureaucracy undergoes change. For Weber, an ideal bureaucracy covered a fixed area of activity, governed by rules and based on written documents, was organized as a hierarchy, required a degree of expert training, and its officials devoted all their time to their work within an office environment that followed general rules which could be learned. He also noted that officials who are elected display less of a tendency towards bureaucracy, an important observation in the context of British sport given that patrimonial amateur administrators are traditionally elected by their peers (SWEDBERG; AGEVALL, 2005).

In the 1990s, government reports and strategic documents started to make an impact on the operation of the BOA, a process accelerated by the IOC awarding the Games to London in 2005. UK Sport, the government organization responsible for developing elite-level sport, was established in 1997 and authorized to distribute lottery funding. In 2017 to 2018, UK Sport's total expenditure was $£ 157.7$ million, nearly 94 percent of this in grants and related payments to NGBs, athletes, and major events (UK SPORT: THE NATIONAL LOTTERY). 
UK Sport has adopted a target driven agenda whereby sports are funded according to whether or not they achieve medal targets, and the twenty-first-century record of four Olympic sports, athletics, rowing, cycling and swimming, demonstrate this process quite clearly (UK SPORT: INVESTING IN SPORT). Cycling has consistently exceeded its targets, and this is reflected in the continuous growth of its funding. Similarly, rowing met its targets up until Rio, although underperforming here resulted in their funding being reduced for Tokyo. Athletics failed to meet its target in Beijing and saw its funding fall for the following Olympic cycle while swimming failed to reach expectations for the London Games and saw a significant reduction in funding for Rio. Exceeding their medal target in Rio has resulted in additional funding for Tokyo 2020.

Despite criticisms of this level of expenditure, and indeed of the whole process of rationalization, there is no indication that the British government is prepared to abandon its commitment to achieving Olympic results (and the status that comes with success). The focused investment of the last twenty years has resulted in a marked change in British fortunes, and formal reviews of the elite sporting agenda in the wake of the Rio Games show no signs of deviating from the established template. Following a strategic review of its performance investment policy in preparation for Tokyo, UK Sport concluded that it would continue to focus on medal success and to concentrate on Olympic and Paralympic sports (UK SPORT: INVESTING IN SPORT).

\section{Reflections}

While there were occasional signs that the amateur hegemony could become more pliable when placed under pressure, especially following poor Olympic performances, which suggests that ICH is not immutable, it did remain relatively static for much of the twentieth century. However, although British sport continued to be dominated by the amateur into the $1980 \mathrm{~s}$, the transition of rugby union into a professional sport in 1995 signalled that 'amateurism' as a sporting philosophy had eventually lost its traditional hold on elite sport. Several factors had contributed to this process. An increasingly professionalized society began to reject the notion of the 'amateur', which soon became a derogatory term, and there was an accompanying decline in the number of top-class amateurs in sports like cricket. In addition, during the second half of the twentieth century, the possession of an education, which had previously distinguished the social elite, became more commonplace through mass secondary education and the expansion of the universities. Hitherto the social elite had been a relatively closed and circumscribed social group, sharing not only culture in common but also background, schooling, social networks, and experience (DIMAGGIO, 1997). Alongside these developments, the media became more strident in its criticisms of the failures of British teams (HOLT; MASON, 2000), and the BOA increasingly found itself in difficulty. One of the fundamental functions of the BOA was to provide the funding and organization to ensure that a Great Britain team competed at the Olympic Games. Between 1936 and 1976, financial support came from nationwide public appeals but, after the Government pressured the BOA to boycott the 1980 Moscow Olympics, the BOA was forced to subsidize a British team from its own funds, a move which left it virtually bankrupt. The end result was that government involvement, albeit not on the Soviet scale, became acceptable, and this led to increasing resources being devoted to the pursuit of 
Olympic success (HEGGIE, 2008).

The 2000 Sydney Games marked the beginning of a turnaround in Britain's Olympic fortunes that would culminate in its second place in the medal table in Rio. This revival had its roots in growing state intervention in sport and, most importantly, the availability of National Lottery funding (GREEN, 2007), which brought with it much greater investment at an elite level. In this respect, Britain finally joined other nations in its approach to sporting excellence, and some of the outward vestiges of amateurism were removed. The problem is that the ICH of amateurism, shaped by the patrimonial elites of the late nineteenth century, has become so deep-rooted in the British psyche that, despite the government interventions of the last twenty years that have encouraged an industrialized, outcome-driven approach to elite sport, there remains a reluctance to embrace the concept of progress. ICHs in general can be highly resistant to change, and amateurism was so ingrained into the sporting culture that changes were always slow and highly contested. While the British approach has subsequently been refined by recurrent responses to wider social and cultural developments, such as the increasing demands placed on a sport by the government, the public, and the media, it remains rooted on a bedrock of amateurism established by a cultural heritage elite.

The powerful influence of the British class system was constantly reflected in the way in which amateur principles were applied by this cultural elite, during the twentieth century and it is no surprise that, despite a shift in emphasis to government-sponsored bureaucratic rationalization, the legacy of the cultural elite that has run British Olympic sport since its inception remains powerful and social class, combined with a privileged education, retains it potency. A study of over 1,400 elite athletes at the beginning of the twenty-first century identified that 20 percent had been educated in private schools and that the proportion of elite athletes emerging from higher social class families was much higher than from any other group. In the 2012 Games, 35 percent of British medallists had attended an independent school, and in 2016 this figure was 31 percent. Over half (52 percent) of medal-winning rowers attended fee-paying schools in 2016, along with 50 percent of the winning women's hockey team. Team GB has been frequently lauded for their success at 'sitting down sports', including rowing, cycling, sailing, and equestrianism, which are sports historically associated with higher social classes, and involve specialized and frequently expensive equipment and facilities. The role of independent schools in many such sports is reflected in the fact that an Old Etonian has won a medal in these sports at every Olympic Games since 1992. Even at participation levels, socioeconomic background and education levels have been shown to be significantly associated with regular sporting activity (THE SUTTON TRUST, 2019).

None of this should really be a surprise given that narrow class interests still dominate the wider social and political landscape. Britain remains a class-ridden society. Of the 26 Prime Ministers since 1885, nine have come from Eton, fifteen went to Oxford University (including eleven out of the last fifteen), and three to Cambridge. The current British Cabinet is the most privately educated for over a generation with almost two-thirds (65 percent) having attended private school. Members of the cabinet are over nine times more likely to have gone to an independent school than the general population. Of the 26 ministers in Boris Johnson's new cabinet, half (50 percent) went to Oxford or Cambridge Universities, which compares with 27 percent of all Conservative MPs, 18 percent of Labour MPs, and 24 percent of all MPs. Overall, 31 percent of the cabinet went through a 'pipeline' from fee-paying schools to Oxbridge (SUTTON TRUST, 2020). 


\section{Bibliography}

AAA ANNUAL REPORT, 1953.

AAA MEMORANDUM to NFC May 10, 1937, File ED 113/54, NFC Collection: AAA 1937-39, National Archives, Kew.

ABRAHAMS, Harold. Sir Adolphe Abrahams memorial lecture 'The changing face of international sport', Bulletin of the British Association of Sports Medicine 3, 1968, 164-168.

ANTHONY, Don. A Strategy for British Sport. London: C Hurst \& Co., 1980.

BAKER, Neil. Whose Hegemony? The Origins of the Amateur Ethos in Nineteenth Century English Society. Sport in History 24(1), (2004), 14.

BANNISTER, Roger. First Four Minutes. London: Putnam, 1955.

BARKER, Philip. The British Olympic Association 1905-2005 - A Chronology. Journal of Olympic History 13, May/June 2005, 2, 64-72.

BLAU, J. R. The Elite Arts, More or Less de Rigueur: A Comparative Analysis of Metropolitan Culture. Social Forces 64(4), 1986, 875-905.

BLAU, J. R. The Shape of Culture. Cambridge University Press, Cambridge, 1989.

BOOTH, D. and LOY, J. Sport, Status, and Style. Sport History Review, 30, 1999, 1-26.

BOURDIEU, Pierre. Distinction: A Social Critique of the Judgment of Taste. Harvard University Press, Cambridge, MA, 1984.

BRAILSFORD, Dennis. British Sport: A Social History. Cambridge: The Lutterworth Press, 1992, 122.

BUCKLAND, Michael. Cultural Heritage (Patrimony): An Introduction, In Ed. by WILLER, Mirna, GILLILAND, Anne J. and TOMIĆ Marijana. Zadar, Records, Archives and Memory: Selected Papers from the Conference and School on Records, Archives and Memory Studies, University of Zadar, Croatia, May 2013, 2015, 11-25.

C. WRIGHT MILLS. The Power Elite, Oxford: Oxford University Press, 1956.

CARPENTER, Tegan. Uneasy Bedfellows: Amateurism and Coaching Traditions in Twentieth Century British Sport. PhD diss., Manchester Metropolitan University, 2012. 
CHANEY, D. The Cultural Turn. London: Routledge, 1994.

CZAJKOWSKI, Pawel, PABJAN, Barbara, ZUBER, Marcelina (ed.): Pamięć i przestrzeń. Forum Socjologiczne. Wrocław: Wydawnisktwo Uniwersytetu Wrocławskiego, 2016, 23.

DAILY EXPRESS, August 14, 1936, 3

DAILY MIRROR, August 14, 1936, 3

DAY, Dave. Professionals, Amateurs and Performance: Sports Coaching in England, 1789-1914. Bern: Peter Lang, 2012.

DAY, Dave and STOKLASA, Jana. Urban Image Management in Wroctaw and the British Olympic Association: A Transcultural Approach to Social Elites and Their Influence in Europe. Joint LUH and MMU Workshop, Leibniz University, Hannover, 30-31 October 2019.

DIMAGGIO, P. The Sociology of Culture. Cambridge: Cambridge University Press, 1997.

DUNCAN, K. S. Great Britain and Olympism, Olympic Review 99-100, January-February 1976, 54-91.

ELITE CULTURE. http://sociology.iresearchnet.com/sociology-of-culture/elite-culture/

FOREIGN OFFICE TO H.M. REPRESENTATIVES OVERSEAS, 16 July 1959. PRO: TNA: FO371/145547/ W1801, Kew.

GREEN, M. Olympic glory or grassroots development? Sport policy priorities in Australia, Canada and the United Kingdom, 1960-2006. The International Journal of the History of Sport, 24 (7), 2007, 921-953.

GRUNEAU, R. Class, Sports and Social Development. Amherst: University of Massachusetts Press, 1983.

HALL, P.A. Social Capital in Britain, British Journal of Political Science, 29(3), 1999, 417-421.

HARGREAVES, J. Sport, Power and Culture: A Social and Historical Analysis of Popular Sports in Britain. Cambridge, UK: Polity, 1986.

HARGREAVES, J. The Body: Sport and Power Relations. In HORNE, J. JARY, D. and TOMLINSON A. (Eds.), Sport, Leisure and Social Relations. London: Routledge \& Kegan Paul, 1987, 139-159.

HARVEY, David. C. Heritage pasts and heritage presents: Temporality, meaning and the scope of heritage studies. International Journal of Heritage Studies, 7 (4), 2001, 319-38. 
HEGGIE, Vanessa. 'Only the British Appear to be Making a Fuss': The science of success and the myth of amateurism at the Mexico Olympiad, 1968. Sport in History, 28 (2), 2008, 213-35.

HOLT, Richard, and MASON, Antony. Sport in Britain, 1945-2000. Chichester: John Wiley \& Sons, 2000.

HONEY J. R. De S. and CURTHOYS M. C., Oxford and Schooling, In BROCK, M. G. and CURTHOYS, M. C., The History of the University of Oxford, vii: 19th-Century Oxford, Pt. 2. Oxford, 2000, 545-69.

HOULIHAN, Barrie. Sport, National Identity and Globalisation. The Centre for Research into Sport and Society, University of Leicester, 1998, 11-20.

HUGGINS, Mike, and WILLIAMS, J. Sport and the English, 1918-1939 London: Routledge, 2006, 122, 130.

KELLER, Suzanne Infeld. Beyond the Ruling Class: Strategic Elites in Modern Society. Abingdon, Oxford: Routledge, 2017. Originally published in 1963 by Random House, Inc., 30-31.

KURIN, R. Safeguarding Intangible Cultural Heritage in the 2003 UNESCO Convention: A critical appraisal. Museum International, 56 (1-2), 2004, 67.

LACHMANN, Richard. Coda: American Patrimonialism: The Return of the Repressed. The Annals of the American Academy of Political and Social Science, 636 (1), 2011, 204-230.

LEIMGRUBER, W. Switzerland and the UNESCO Convention on intangible Cultural Heritage. Journal of Folklore Research, 47 (1/2, January -August), 2010, 161-196.

MANCHESTER GUARDIAN, 13 December 1935, 3. 'List of Volunteer Lecturers.'

MATLESS, David. Landscape and Englishness London, 1998, 14, 25-100.

OBSERVER, August 16, 1936, 12.

PERKIN, Harold. The Rise of Professional Society: England since 1880. Oxon: Routledge, 1989, 218.

PICTURE POST, 2 February 1952, 8. 'Letter to the editor. Amateurs: No such thing?'

PICTURE POST, 31 December 1956. 'Letter to the editor'.

PICTURE POST, 9 August 1952, 12-13. 'Letter to the editor. Geoffrey Hoare. Training by Candlelight?’

READMAN, P. The Place of The Past in English Culture C.1890-1914 Past and Present, 2005, 198-199. 
RUBINSTEIN, William D. The social origins and career patterns of Oxford and Cambridge matriculants, 18401900. Historical Research, 82, (218), November 2009, 715.

RUBINSTEIN, William D. Capitalism, Culture, and Decline in Britain, 1750-1990 (1993), 102-39.

SATURDAY REVIEW, 17 August 1912, 195-96.

SEWELL, William. The Concept(s) of Culture, In BONNELL, Victoria E. and HUNT, Lynn (eds.) Beyond the Cultural Turn New Directions in the Study of Society and Culture, Berkeley, Los Angeles, London: University of California Press, 1999, 44.

SMITH, Laura Jane, Uses of Heritage. London and New York: Routledge, 2006, 109.

STAR GREEN ‘UN, 10 August 1957, 8.

SUTTON TRUST. Elitist Britain: The Educational Backgrounds of Britain's Leading People, 2019, 81.

SUTTON TRUST CABINET ANALYSIS, https://www.suttontrust.com/our-research/sutton-trust-cabinetanalysis-2020/, 2020.

SWEDBERG, Richard and AGEVALl, Ola. The Max Weber Dictionary: Key Words and Central Concepts. Stanford University Press, 2005.

THE LITERARY DIGEST 45 (31 August 1912), 30. 'Ill Training and Snobbery in British Athletics'.

THE TIMES, 22 October 1913, 12.

THE TIMES, 7 August 1952. 'Mr. H. Abrahams on the Olympic Games'.

TOLBERT, P. S. Robert Michels and the iron law of oligarchy [Electronic version]. Retrieved from Cornell University, ILR School site: http://digitalcommons.ilr.cornell.edu/articles/397/, 2010.

TOMLINSON, Alan, MARKOVITS, Andrei S., YOUNG, Christopher. Mapping Sports Space. American Behavioral Scientist, 46 (11), July 2003, 1469-1470.

UK SPORT. ‘Elite Coach’ www.uksport.gov.uk/pages/elite-coach/ Accessed 23.01.2011

UK SPORT. 'Investing in Sport', http://www.uksport.gov.uk/our-work/investing-in-sport. Accessed 01.09.2018

UK SPORT. 'The National Lottery,' http://www.uksport.gov.uk/about-us/partners/the-national-lottery (Accessed 
20.08.2018).

WAKEFIELD, W. W. and MARSHALL, H. P. Rugger. London: Longmans, Green and Co. Ltd, 1927, 8, 40-41, $66-67,70$.

WEBER, Max. Economy and Society. Berkeley and Los Angeles, Ca.: University of California Press, 1922/1978.

WHITSON, David, 'Sport and Hegemony: On the Construction of the Dominant Culture'. Sociology of Sport Journal, 1, (1984): 64-78.

WOLFENDEN REPORT. Sport and the Community. London: Eyre \& Spottiswood, 1960.

YORKSHIRE POST AND LEEDS INTELLIGENCER, 5 February 1935, 19.

RECEBIDO EM: 17/03/2020

APROVADO EM: 30/03/2020 